\title{
Variability in Physician Care Practices for Glucose Treatment in Stroke Patients
}

\author{
Leanne K. Casaubon, Alexandra Saltman, Valentina Peeva, Marguerite Ennis, \\ Ngan Lam, Frank L. Silver, Moira K. Kapral
}

\begin{abstract}
Background: Hyperglycemia is noted in up to $60 \%$ of stroke patients. Practice guidelines recommend glucose monitoring following stroke but provide few management recommendations. We examined physician care practices for glucose management in stroke patients. Methods: Emergency physicians, family physicians, general internists, intensive care specialists and neurologists in Ontario comprised the study population. A mailed, self-administered survey inquired about glucose management practices. Proportions of responses for survey questions were determined. Chi-square analysis was used for comparing physician groups. Results: Surveys were mailed to 2,280 physicians; $26.8 \%$ returned surveys. There were 278 respondents who reported providing stroke patient care. For physicians treating glucose in stroke patients, 16.6\% targeted glucose 4.0-6.0 mmol/1, 52\% targeted 6.1-8.0 mmol/1, $13.6 \%$ targeted $8.1-12.0 \mathrm{mmol} / 1,0.8 \%$ targeted $12.1-15.0 \mathrm{mmol} / \mathrm{l}$, and $7.5 \%$ were unsure. Comparing specialties, $32 \%$ of intensivists, $17.5 \%$ of neurologists, $13 \%$ of general internists, $14 \%$ of emergency physicians, and $0 \%$ of family physicians reported targeting $4.0-6.0$ $\mathrm{mmol} / \mathrm{l}(\mathrm{p}=0.026)$. Overall, 44\% reported aiming for target glucose within 12 hours and $77 \%$ within 24 hours from hospital presentation. Intensive care specialists treated glucose most aggressively, including $20 \%$ treating, with insulin infusion, patients with no diabetes and initial glucose 6.0-8.0 mmol/1. Emergency physicians were most conservative when treating glucose in stroke patients. Conclusion: There is variability in the aggressiveness of glucose management in stroke patients by different physician specialty groups, reflecting the lack of evidence available to guide hyperglycemia management in this setting. These results highlight an important gap in knowledge and recommendations for stroke patient care that must be addressed to ensure optimal patient outcomes.
\end{abstract}

RÉSUMÉ: Variabilité de l'attitude thérapeutique des médecins concernant le glucose chez les patients atteints d'un accident vasculaire cérébral. Contexte : Près de $60 \%$ des patients atteints d'un accident vasculaire cérébral (AVC) présentent une hyperglycémie. Les lignes directrices recommandent de surveiller le glucose après un $\mathrm{AVC}$, mais elles fournissent peu de recommandations de traitement. Nous avons examiné les pratiques des médecins à ce sujet. Méthodes : La population de l'étude était constituée des urgentologues, des médecins de famille, des internistes, des intensivistes et des neurologues de l'Ontario. Nous avons distribué par la poste un questionnaire à compléter au sujet de leur attitude thérapeutique concernant le glucose. Nous présentons les réponses aux questions de l'enquête sous forme de proportions. Le test du chi-carré a été utilisé pour comparer les groupes de médecins. Résultats : Des questionnaires ont été postés à 2280 médecins; 26,8\% ont retourné le questionnaire. Deux cent soixante-dix-huit répondants ont rapporté qu'ils traitaient des patients porteurs d'AVC. Parmi ceux qui traitaient le glucose chez les patients porteurs d'un AVC, $16,6 \%$ ciblaient un glucose entre 4,0 et $6,0 \mathrm{mmol} / \mathrm{L}, 52 \%$ ciblaient un glucose entre 6,1 et $8,0 \mathrm{mmol} / \mathrm{L}, 13,6 \%$ ciblaient un glucose entre 8,1 et $12,0 \mathrm{mmol} / \mathrm{L}, 0,8 \%$ ciblaient un glucose entre 12,1 et $15,0 \mathrm{mmol} / \mathrm{L}$ et 7,5\% étaient indécis. Si nous comparons les réponses par spécialité, $32 \%$ des intensivistes, $17,5 \%$ des neurologues, $13 \%$ des internistes, $14 \%$ des urgentologues et $0 \%$ des médecins de famille ont rapporté une cible de 4,0 à 6,0 $\mathrm{mmol} / \mathrm{L}(\mathrm{p}=0,026)$. Dans l'ensemble, $44 \%$ ont rapporté un chiffre cible pour le glucose dans les 12 heures et $77 \%$ dans les 24 heures de l'arrivée du patient à l'hôpital. Les intensivistes étaient ceux qui traitaient le glucose de la façon la plus agressive et $20 \%$ d'entre eux traitaient les patients non diabétiques avec un glucose initial de 6,0 à $8,0 \mathrm{mmol} / \mathrm{L}$ par une infusion d'insuline. Les urgentologues étaient les plus conservateurs dans le traitement du glucose chez les patients porteurs d'un AVC. Conclusion : Il existe une certaine variabilité dans l'attitude thérapeutique de différents groupes de spécialistes concernant le glucose chez les patients présentant un AVC. Cette constatation reflète l'absence de données pour guider le traitement de l'hyperglycémie dans ce contexte et souligne une lacune importante dans les connaissances et les recommandations thérapeutiques sur l'AVC qu'on devra combler pour optimiser le pronostic des patients atteints d'AVC.

Can. J. Neurol. Sci. 2008; 35: 573-582

Elevated blood glucose is found in $20 \%$ to $60 \%$ of patients presenting to hospital with stroke, ${ }^{1,2}$ and has been associated with increased mortality and morbidity even in the absence of a pre-existing diagnosis of diabetes mellitus. A postulated mechanism for the elevation in glucose levels is a physiologic stress response from the acute stroke insult that results in hormonal changes in the pathway regulating systemic glucose..$^{3-5}$ In addition, an association between hyperglycemia
From the University Health Network (LKC, AS, VP, NL, FLS, MKK); University of Toronto (LKC, FLS, MKK), Toronto; Applied Statistician (ME), Markham, Ontario, Canada.

Received April 9, 2008. Final Revisions Submitted June 13, 2008 Correspondence to: Leanne K. Casaubon, Dept. of Medicine, University of Toronto, Division of Neurology - Stroke Program, Toronto Western Hospital, West Wing 5-448, 399 Bathurst St., Toronto, ON, M5T 2S8, Canada. 
and increased mortality, after adjusting for initial stroke severity, has been shown in several observational cohort studies. These findings suggest a possible deleterious effect of elevated blood glucose beyond it being a simple marker of the cerebral injury. 6,7

The effects of elevated blood glucose have been observed in animal models of stroke. In experimental models of either global or focal ischemia, hyperglycemia preceding stroke onset was associated with increased cerebral damage and worse functional outcome. ${ }^{8-10}$ Pathological processes documented in these hyperglycemic animals include augmented intracellular acidosis and increased neuronal cell death, ${ }^{11}$ worsened cerebral edema, ${ }^{8,12}$ and an increased tendency for secondary hemorrhage. Reversal of initial hyperglycemia has been shown to limit the extent of cerebral infarction in animal models. ${ }^{13}$

Elevated glucose has also been associated with increased mortality and worse functional outcome in human studies of patients with acute myocardial infarction and patients in intensive care. ${ }^{14-16}$ The treatment of elevated blood glucose in these medical settings has been associated with lower mortality and morbidity in several studies. ${ }^{17-19}$ A meta-analysis of nine studies of patients with myocardial infarction showed an overall $28 \%$ risk reduction for in-hospital mortality (odds ratio 0.72 , $95 \%$ CI $0.57-0.90, p=0.004) .{ }^{20}$ In ICU patients, an overall $15 \%$ decrease in mortality has been shown. ${ }^{19}$ In stroke patients, the Glucose in Stroke Trial (GIST-UK) was the first randomized trial of glucose lowering using an intravenous insulin infusion compared to a normal saline control infusion. ${ }^{21}$ This study of 933 patients showed no difference in 90-day mortality or functional disability in stroke patients treated with insulin infusion compared to controls. However, the study did not reach its recruitment target and was likely underpowered to demonstrate a difference between the treatment and control groups. Moreover, GIST study patients had only modestly elevated glucose levels at enrollment (median $7.6 \mathrm{mmol} / \mathrm{l}$, interquartile range $6.7-9.0$ $\mathrm{mmol} / \mathrm{l}$ ) and glucose spontaneously decreased in the control group to within the study target level over 24 hours, making it plausible that a true difference between the treatment and control groups was simply not demonstrated. Other smaller studies have shown safety of glucose lowering in stroke patients, but none have evaluated patients for outcomes like mortality or functional disability.

Currently, Canadian practice guidelines recommend that blood glucose be evaluated and closely monitored in patients following stroke. ${ }^{22}$ These guidelines provide no specific direction to physicians regarding the level above which they might consider treating glucose or what glucose level to target if treatment is initiated. Also, there is no guidance as to which treatment strategies are optimal. Practice guidelines from the American Stroke Association make a stronger statement to consider initiating treatment of glucose above levels of $>7.8$ to $10.3 \mathrm{mmol} / \mathrm{l}$ in patients with ischemic and hemorrhagic stroke, though the evidence supporting these statements is limited. ${ }^{23,24}$ We set out to examine the current care practices of physicians in Ontario in the management of hyperglycemia in patients with stroke using a self-report questionnaire. The main goal of this study was to determine whether there are differences in management strategies between different physician specialty groups involved in the care of stroke patients.

\section{METHODS \\ Physician Sample}

A list of physicians was generated using the Canadian Medical Directory. The main selection criterion for the survey sample was a hospital-affiliated medical practice based in Ontario. Both English and French speaking physicians were included. We targeted the following specialties: emergency medicine, family medicine, internal medicine, intensive care, and neurology.

\section{Survey Development}

A questionnaire was created as a self-report survey of physician care practices for glucose management in stroke patients (see Appendix). We obtained demographic information pertaining to physicians' work environments and clinical practice details, and inquired about their involvement in providing care to stroke patients. Only physicians who reported providing care to stroke patients completed the remainder of the survey questions regarding their understanding of the impact of hyperglycemia in stroke patients and their knowledge of management recommendations for hyperglycemia in stroke patients based on existing evidence. The survey also examined in detail how physicians who did provide care for stroke patients approached the management of glucose in stroke patients based on specific patient scenarios, including stroke patients with no history of diabetes or diet-controlled diabetes (Scenario 1), patients on oral hypoglycemic agents for previously diagnosed diabetes (Scenario 2), and patients on subcutaneous insulin for previously diagnosed diabetes (Scenario 3). For Scenario 1, the management choices included: no treatment, oral hypoglycemic agents, sub-cutaneous insulin, insulin infusion, or unsure. For Scenario 2, management choices included: continue same medications, increase oral agent doses, subcutaneous insulin, insulin infusion, or unsure. For Scenario 3, management choices included: continue same subcutaneous insulin dose, increase subcutaneous insulin dose, insulin infusion, other, or unsure. Insulin infusion was considered the most aggressive form of glucose therapy. The proportion of physicians choosing a specific therapy was determined across the range of glucose values above $6.0 \mathrm{mmol} / \mathrm{l}$.

The questionnaire was mailed out to the entire physician sample, but a web-based version was also created to allow physicians to complete the survey online. A cover letter explained the purpose of the study and provided the web address where the survey could be accessed online. Usual methods to enhance survey response rate were used (designing a clear and concise survey, self-addressed return envelopes, reminder sent to physicians). ${ }^{25,26}$

\section{Statistical Analysis}

The proportion of physicians responding to the survey was calculated. Baseline characteristics for non-responders were compared to responders (including physician specialty group, language, and location of medical practice). Of the returned surveys, baseline characteristics of physicians who did and did not treat stroke were compared. The proportion of physicians who responded to each survey question choice regarding the treatment of glucose was determined. Chi-square analysis was 
used for comparisons between physician groups. A mean treatment aggressiveness score was derived by designating a numeric value for each possible treatment selection in the survey questions pertaining to glucose management (see Appendix, questions 14 - 16) and calculating a mean for each physician specialty group. For example, responses for question 14 were designated as "no treatment" = 0 , "oral agents" = 1 , "insulin subcutaneously" $=2$, and "insulin intravenously" $=3$. Mean scores were represented graphically to provide a visual depiction of any differences in management practices between specialty groups.

\section{Ethics and Confidentiality}

Consent to participate in the study was implied if the physician completed and returned the survey; this was explained in the cover letter. Identifying information was not included on the returned surveys to maintain confidentiality of respondents. This study was approved by the Research Ethics Board of the University Health Network.

\section{Results}

The survey was mailed out to 2,280 physicians across the province of Ontario. Survey responses were received from 610 physicians (26.8\%). Two returned surveys were blank; 608 surveys were included in the study. Generally, there was a $<6 \%$ non-response rate for individual survey questions. Based on postal codes, physician respondents were equally represented across all geographic regions of Ontario. ${ }^{27}$ Comparing respondents to non-respondents, there was no difference in response rate for certified specialists versus general practitioners. However, of the total surveys sent out to each physician group, there was a lower proportion of emergency physicians who responded versus other groups $(\mathrm{p}=0.003)$. Other nonrespondents had specialty designations in surgery, anesthesia, pathology and laboratory medicine, and sub-specialties in medicine.

\section{Demographics of Respondents}

In the total group of respondents, $72.2 \%$ were male and $27.7 \%$ were female. Fifty-one percent of male physicians versus $39.4 \%$ of female physicians reported managing stroke patients ( $\mathrm{p}$ $=0.018)$. Overall, $278(45.7 \%)$ respondents reported providing care to stroke patients. A majority of respondents reported practicing in an academic centre, representing $53.8 \%$ of the physician sample that manage stroke patients. The breakdown of physician respondents by specialty is shown in Table 1. Emergency physicians, general internists, and neurologists were more likely to manage stroke patients compared to other specialists $(\mathrm{p}<0.0001)$. Neurologists were more likely to treat $>$ 20 stroke patients per month, compared to over $58 \%$ of other specialty physicians who treated only one to five per month ( $\mathrm{p}<$ $0.0001)$. Intensive care specialists $(81.8 \%)$ and neurologists $(76.7 \%)$ most frequently reported having a stroke unit (either a dedicated stroke unit or a nursing unit with clustering of stroke patients) in their institution. A multidisciplinary stroke team was reported to be available by $86 \%$ of intensive care specialists, $77 \%$ of neurologists, $65 \%$ of emergency physicians, $60 \%$ of general internists, and $33 \%$ of family physicians. The majority of physicians had a stroke expert at their facility, though only $16.7 \%$ of family physicians reported having access to a stroke expert.

Regarding physician awareness of general practice guidelines for the management of hyperglycemia, approximately one-third to one-half of all physicians acknowledged being aware of such guidelines. Fifty percent of intensive care specialists reported having a specific management protocol for patients with elevated glucose, whereas less than $35 \%$ of the other specialty physicians were aware of such a protocol at their institution. Of those physicians who either were aware of a practice guideline or had a specific hospital protocol, $67 \%$ of intensive care specialists, $67 \%$ of family physicians, $52 \%$ of neurologists, $42 \%$ of emergency physicians, and $33 \%$ of general internists stated that they

Table 1: Physician respondents by specialty (total sample and physicians treating stroke patients)

\begin{tabular}{lrrrr}
\hline \multicolumn{1}{c}{ Specialty } & \multicolumn{2}{c}{$\begin{array}{c}\text { All Respondents } \\
(\mathrm{n}=608)\end{array}$} & \multicolumn{2}{c}{$\begin{array}{c}\text { Physicians Who Manage } \\
\text { Stroke Patients } \\
(\mathrm{n}=278)\end{array}$} \\
\cline { 2 - 5 } & $\mathrm{n}$ & $\%$ & $\mathrm{n}$ & $\%$ \\
\hline Emergency Medicine & 98 & 16.8 & 97 & 35.7 \\
Family Medicine & 14 & 2.4 & 6 & 2.2 \\
Internal Medicine & & & & \\
$\quad$ General/unspecified & 76 & 13.0 & 55 & 20.2 \\
$\quad$ Subspecialty & 174 & 29.8 & 26 & 9.6 \\
Intensive Care & 23 & 3.9 & 22 & 8.1 \\
Neurology & 85 & 14.6 & 61 & 22.4 \\
Other & 113 & 19.4 & 5 & 1.8 \\
Specialty not known & 25 & 4.1 & 6 & 2.2 \\
\hline
\end{tabular}


Table 2: Treatment of stroke patients with no history of diabetes or diet-controlled diabetes

\begin{tabular}{|c|c|c|c|c|c|c|c|c|c|c|}
\hline & \multicolumn{2}{|c|}{$\begin{array}{c}\text { Glucose* }^{*} \\
6.0-8.0 \\
\end{array}$} & \multicolumn{2}{|c|}{$\begin{array}{l}\text { Glucose } \\
8.1-10.0 \\
\end{array}$} & \multicolumn{2}{|c|}{$\begin{array}{c}\text { Glucose } \\
10.1-12.0\end{array}$} & \multicolumn{2}{|c|}{$\begin{array}{c}\text { Glucose } \\
12.1-16.0 \\
\end{array}$} & \multicolumn{2}{|c|}{$\begin{array}{c}\text { Glucose } \\
>16.0\end{array}$} \\
\hline & $\mathrm{n}$ & $\%$ & $\mathrm{n}$ & $\%$ & $\mathrm{n}$ & $\%$ & $\mathrm{n}$ & $\%$ & $\mathrm{n}$ & $\%$ \\
\hline No treatment & 234 & 88.6 & 149 & 55.6 & 60 & 22.5 & 14 & 5.2 & 5 & 1.9 \\
\hline Oral agents & 2 & 0.8 & 21 & 7.8 & 16 & 6.0 & 6 & 2.2 & 1 & 0.4 \\
\hline Subcutaneous insulin & 13 & 4.9 & 55 & 20.5 & 123 & 46.1 & 154 & 57.5 & 123 & 46.8 \\
\hline Insulin infusion & 6 & 2.3 & 25 & 9.3 & 45 & 16.9 & 77 & 28.7 & 116 & 44.1 \\
\hline Unsure & 9 & 3.4 & 18 & 6.7 & 23 & 8.6 & 17 & 6.3 & 18 & 6.8 \\
\hline
\end{tabular}

* Glucose units in mmol/l

Table 3: Treatment of stroke patients with diabetes previously managed with oral hypoglycemic agents

\begin{tabular}{|c|c|c|c|c|c|c|c|c|c|c|}
\hline & \multicolumn{2}{|c|}{$\begin{array}{c}\text { Glucose* }^{*} \\
6.0-8.0\end{array}$} & \multicolumn{2}{|c|}{$\begin{array}{l}\text { Glucose } \\
8.1-10.0\end{array}$} & \multicolumn{2}{|c|}{$\begin{array}{c}\text { Glucose } \\
10.1-12.0\end{array}$} & \multicolumn{2}{|c|}{$\begin{array}{c}\text { Glucose } \\
12.1-16.0\end{array}$} & \multicolumn{2}{|c|}{$\begin{array}{c}\text { Glucose } \\
>16.0\end{array}$} \\
\hline & $\mathrm{n}$ & $\%$ & $\mathrm{n}$ & $\%$ & $\mathrm{n}$ & $\%$ & $\mathrm{n}$ & $\%$ & $\mathrm{n}$ & $\%$ \\
\hline Continue same OHA & 201 & 78.2 & 137 & 52.3 & 54 & 20.5 & 12 & 4.5 & 8 & 3.1 \\
\hline Increase OHA & 7 & 2.7 & 33 & 12.6 & 40 & 15.2 & 20 & 7.6 & 6 & 2.3 \\
\hline Subcutaneous insulin & 26 & 10.1 & 54 & 20.6 & 110 & 41.7 & 146 & 55.3 & 122 & 46.6 \\
\hline Insulin infusion & 12 & 4.7 & 26 & 9.9 & 46 & 17.4 & 74 & 28.0 & 112 & 42.7 \\
\hline Unsure & 11 & 4.3 & 12 & 4.6 & 14 & 5.3 & 12 & 4.5 & 14 & 5.3 \\
\hline
\end{tabular}

* Glucose units in mmol/l; OHA=oral hypoglycemic agents

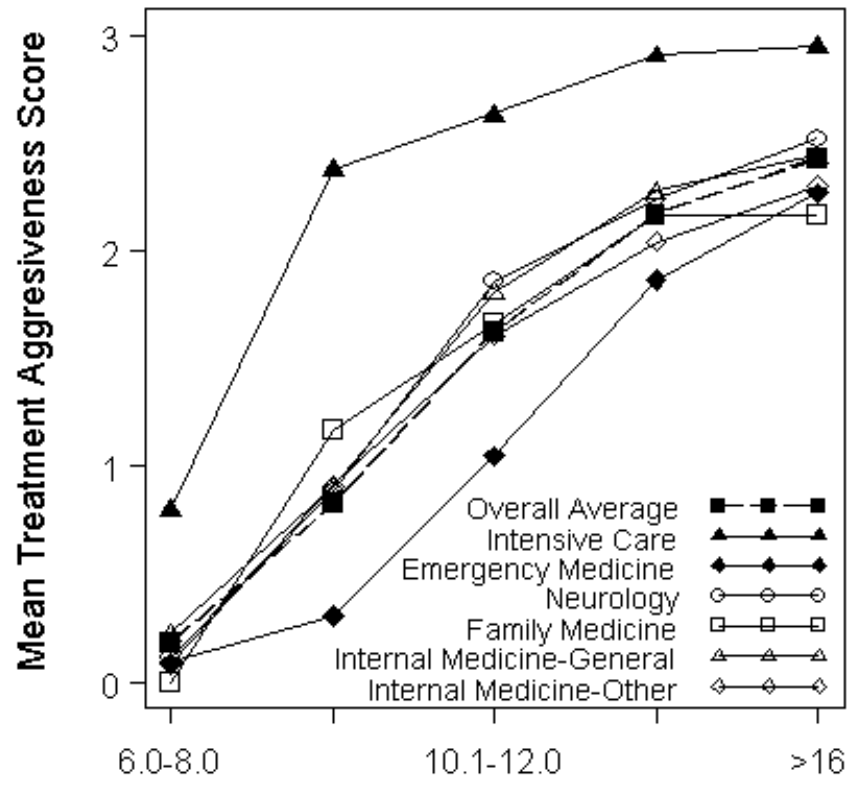

Glucose Level ( $\mathrm{mmol} /)$

Figure 1: Glucose treatment aggressiveness by physician specialty for patients with no history of diabetes or diet-controlled diabetes.

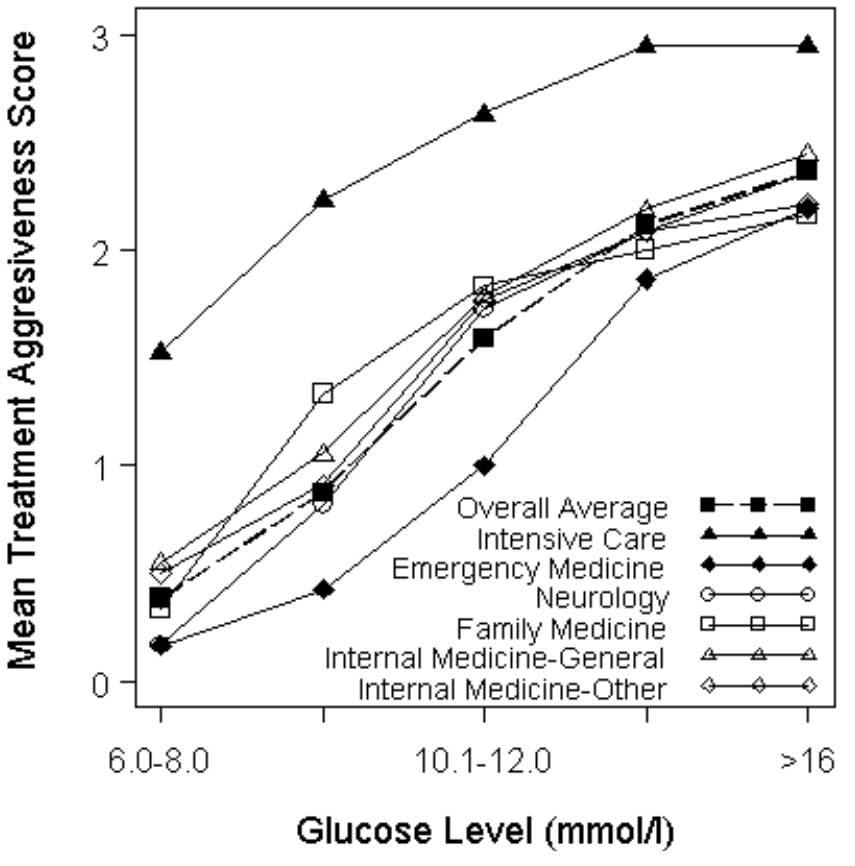

Figure 2: Glucose treatment aggressiveness by physician specialty for patients with diabetes previously managed with oral hypoglycemic agents. 
based their management of glucose in stroke patients on such recommendations.

\section{Management of Glucose in Stroke Patients}

Physicians were more aggressive in the treatment reported with increasing levels of initial glucose in the patient scenarios. However, even in patients without a history of diabetes, $9.3 \%$ of physicians reported they would begin an insulin infusion for an initial glucose $8.1-10.0 \mathrm{mmol} / \mathrm{l}$ (Table 2). This finding was similar in patients with diabetes controlled with oral hypoglycemic agents (Table 3). In stroke patients with diabetes previously treated with subcutaneous insulin, $12.2 \%$ of physicians reported beginning an insulin infusion for glucose 8.1 - $10.0 \mathrm{mmol} / \mathrm{l}$ and $20 \%$ reported beginning insulin infusion for glucose 10.1 - $12.0 \mathrm{mmol} / \mathrm{l}$ (Table 4 ).

When comparing individual physician specialty groups, there was no significant difference in treatment for glucose $6.0-8.0$ $\mathrm{mmol} / \mathrm{l}(\mathrm{p}=0.103)$ in stroke patients with no history of diabetes (or diet-controlled diabetes). In this patient group, most physicians would not initiate treatment, though $20 \%$ of intensive care specialists reported using an insulin infusion. For glucose $8.1-10.0 \mathrm{mmol} / \mathrm{l}, 55 \%$ of intensive care specialists reported treating with an insulin infusion and another $32 \%$ reported beginning subcutaneous insulin. However, in the other physician groups, $50 \%$ of family physicians, internists, and neurologists reported they would not initiate treatment for this patient group and $77 \%$ of emergency physicians reported the same $(\mathrm{p}<$ 0.0001). Differences in glucose management in stroke patients with no history of diabetes (or diet-controlled diabetes) were also observed for glucose 10.1 - $12.0 \mathrm{mmol} / 1,12.1$ - $16.0 \mathrm{mmol} / \mathrm{l}$, and $>16.0 \mathrm{mmol} / \mathrm{l}$. Intensive care specialists were more likely to report using insulin infusion throughout the range of glucose values and emergency physicians were least likely to choose this management strategy $(\mathrm{p}<0.0001)$. Figure 1 illustrates the differences in glucose treatment between physician specialty groups.

In stroke patients with diabetes previously controlled with oral hypoglycemic agents, for glucose $6.0-8.0 \mathrm{mmol} / 1$, intensive care specialists reported using insulin infusion $35 \%$ of the time, whereas all other specialties reported continuing the same oral medications in over $70 \%$ of patients $(p<0.0001)$. This trend continued throughout all glucose ranges, including glucose $>$ $16.0 \mathrm{mmol} / \mathrm{l}$ where $96 \%$ of intensive care specialists, $46 \%$ of general internists, $42 \%$ of neurologists, $33 \%$ of emergency physicians, and $17 \%$ of family physicians reported using insulin infusion ( $\mathrm{p}=0.054$ ) (Figure 2).

Finally, for stroke patients with diabetes previously controlled with subcutaneous insulin, differences in the management persisted between physician groups (Figure 3). Intensive care specialists remained the most aggressive in managing glucose; this group reported the use of insulin infusion in $40 \%$ of patients with glucose between $6.0-8.0 \mathrm{mmol} / \mathrm{l}$ and in a higher proportion of patients with higher glucose levels. For the lowest glucose range, other physician groups reported using insulin infusion in only $10 \%$ of patients; more often they reported increased use of subcutaneous insulin to manage glucose across all ranges.

Examining target blood glucose levels when treatment was initiated, $16.6 \%$ of physicians targeted glucose $4.0-6.0 \mathrm{mmol} / \mathrm{l}$, $52 \%$ targeted $6.1-8.0 \mathrm{mmol} / \mathrm{l}, 13.6 \%$ targeted $8.1-12.0 \mathrm{mmol} / \mathrm{l}$, and $0.8 \%$ targeted $12.1-15.0 \mathrm{mmol} / \mathrm{l}$. Almost $10 \%$ of physicians chose a range other than those provided and $7.5 \%$ were unsure as to their target glucose level. Comparing specialty groups, over $40 \%$ of physicians in any group reported a target glucose range of $6.1-8.0 \mathrm{mmol} / \mathrm{l}$, whereas $32 \%$ of intensive care specialists, $17.5 \%$ of neurologists, $13 \%$ of general internists, $14 \%$ of emergency physicians, and $0 \%$ of family physicians reported a target of $4.0-6.0 \mathrm{mmol} / \mathrm{l}(\mathrm{p}=0.026)$. Overall, $203(77.2 \%)$ physicians reported having a goal of achieving target glucose within 24 hours of patient presentation to hospital and only 34 $(12.9 \%)$ reported using a time frame of $>24$ hours. Comparing specialties, $100 \%$ of intensivists, $86.4 \%$ of neurologists, $80 \%$ of family physicians, $75.8 \%$ of emergency physicians, and $65.4 \%$ general internists would treat glucose to target within 24 hours of patient presentation $(\mathrm{p}<0.0001)$. There were $25(9.5 \%)$ physicians overall who were unsure within which time frame to lower glucose in stroke patients; 16 (64\%) were emergency physicians.

\section{Discussion}

In this survey of Ontario physicians, we found marked variations in the reported management of glucose in stroke patients. As well, some physicians reported treating glucose in

Table 4: Treatment of stroke patients with diabetes previously managed with subcutaneous insulin

\begin{tabular}{|c|c|c|c|c|c|c|c|c|c|c|}
\hline & \multicolumn{2}{|c|}{$\begin{array}{c}\text { Glucose* }^{*} \\
6.0-8.0\end{array}$} & \multicolumn{2}{|c|}{$\begin{array}{l}\text { Glucose } \\
8.1-10.0\end{array}$} & \multicolumn{2}{|c|}{$\begin{array}{c}\text { Glucose } \\
10.1-12.0\end{array}$} & \multicolumn{2}{|c|}{$\begin{array}{c}\text { Glucose } \\
12.1-16.0\end{array}$} & \multicolumn{2}{|c|}{$\begin{array}{c}\text { Glucose } \\
>16.0\end{array}$} \\
\hline & $\mathrm{n}$ & $\%$ & $\mathrm{n}$ & $\%$ & $\mathrm{n}$ & $\%$ & $\mathrm{n}$ & $\%$ & $\mathrm{n}$ & $\%$ \\
\hline Continue same SC ins & 201 & 77.9 & 129 & 49.2 & 37 & 14.0 & 9 & 3.4 & 3 & 1.2 \\
\hline Increase SC ins & 21 & 8.1 & 83 & 31.7 & 155 & 58.7 & 160 & 60.8 & 116 & 45.1 \\
\hline Insulin infusion & 19 & 7.4 & 32 & 12.2 & 55 & 20.8 & 76 & 28.9 & 118 & 45.9 \\
\hline Other & 8 & 3.1 & 7 & 2.7 & 6 & 2.3 & 6 & 2.3 & 7 & 2.7 \\
\hline Unsure & 9 & 3.5 & 11 & 4.2 & 11 & 4.2 & 12 & 4.6 & 13 & 5.1 \\
\hline
\end{tabular}

* Glucose units in mmol/l; SC ins=subcutaneous insulin 
stroke patients at relatively low initial glucose levels. Almost $10 \%$ of physicians reported they would begin an insulin infusion for an initial glucose $8.1-10.0 \mathrm{mmol} / \mathrm{l}$ in stroke patients with no diabetes; physicians were more aggressive in treating glucose at higher initial glucose levels and in patients with diabetes. When physicians initiated treatment for glucose, nearly $70 \%$ had a glucose target $<8.0 \mathrm{mmol} / 1$, including over $15 \%$ who targeted glucose 4.0 - $6.0 \mathrm{mmol} / \mathrm{l}$, and nearly $80 \%$ reported having a goal of achieving target glucose within 24 hours of patient presentation.

We identified significant differences in the approach to the management of glucose in stroke patients between physician specialty groups. Intensive care specialists were most aggressive in treating glucose, including treating patients with no history of diabetes or diet controlled diabetes who present to hospital with glucose 6.0 - $10.0 \mathrm{mmol} / \mathrm{l}$. This finding may relate to prior literature supporting aggressive glucose lowering in intensive care patients, despite the fact that these studies were not conducted in the stroke patient population. Another possible explanation for the more aggressive glucose management by intensivists may relate to staffing and other resources necessary to support using insulin infusion that are available in the ICU. Other physician specialty services care for stroke patients on regular nursing units where glucose management with intravenous insulin may not be practical. Also, emergency physicians often reported deferring glucose management to the internist or consulting specialist, as care would ultimately be transferred to an inpatient service provider within a short time frame from hospital presentation. Both emergency physicians and family physicians also reported that a lack of certainty regarding any guidelines for the management of glucose in stroke patients was a reason for not initiating treatment.

Currently, in stroke patients, optimal blood glucose target levels and the time frame within which targets should be attained are still uncertain. Though the GIST-UK study did not demonstrate a benefit with glucose treatment, limitations in the methodology may have contributed to a negative result. Future studies should carefully choose which stroke patients to include and consider alternative insulin protocols to further evaluate the potential benefits of glucose lowering in stroke patients. Results of our study, showing variability in the current management of glucose in stroke patients and particularly aggressive glucose lowering by some physicians, highlight an urgent need for further studies to clarify the importance of glucose lowering in this patient population. At present, caution should still be exercised to avoid overly aggressive or rapid correction of hyperglycemia, particularly given the deleterious effects of hypoglycemia in stroke patients.

Limitations inherent to surveys may have affected our study results. Responder bias is a potential concern relating to the uncertainty about potential differences in responders compared to the likely responses of non-responders. ${ }^{28} \mathrm{We}$ found no significant differences in the baseline demographics of survey responders versus non-responders, though the management practices of physicians in the non-responder group remain unknown. As well, a large proportion of non-responders had specialty designations in the Canadian Medical Directory database that would not likely be involved in the care of stroke patients in their routine practice. Thus, the higher rate of nonresponders also reflects a limitation in the specificity of

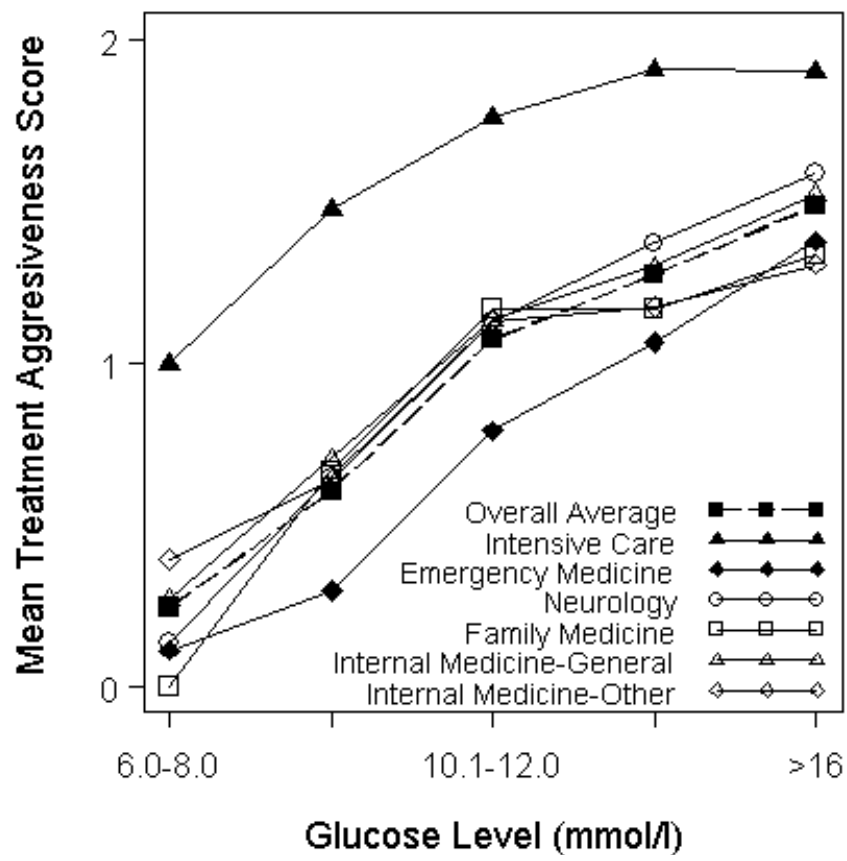

Figure 3: Glucose treatment aggressiveness by physician specialty for patients with diabetes previously managed with subcutaneous insulin.

physician list generation using this database. Nevertheless, the low survey response rate may affect the generalisability of our results. Regarding physician responses, social acceptability bias may be an issue if physicians responded with what they thought would be "correct" responses for treatment questions and not based on their actual practice. ${ }^{28}$ Another limitation of the analysis was that differences in the management of glucose between physician groups were not adjusted for baseline physician and clinical practice characteristics and as such, we cannot make specific conclusions as to why differences exist in these care practices. This limitation would be particularly relevant to the comparison of intensive care specialists and other physician groups, as care practices are possibly guided by resource availability. In addition, though intensive care specialists were shown in this study to treat glucose more aggressively than other specialty groups, overall this physician group would not be involved in the care of the majority of stroke patients in the general population and so the differences in care practices highlighted in this study may be an overestimate. Though our overall sample size was reasonable, there were fewer respondents in certain physician specialty groups and for this reason, we were not able to examine potential differences in glucose management in stroke patients within each physician specialty group that may have also been informative.

We report a wide variability in the aggressiveness of glucose management in stroke patients by different physician specialty groups. Though the specific reasons for these differences need to be further evaluated, the results of our study likely reflect a lack of evidence available to guide physicians in managing hyperglycemia in this setting. Our study highlights an important 
gap in current knowledge and in recommendations for stroke patient care that must be addressed to ensure optimal patient outcomes. Further randomized trials of glucose treatment in stroke patients must be pursued to provide a better understanding of this important issue in stroke care.

\section{ACKNOWLEDGEMENTS}

The authors thank the members of the University Health Network Stroke Program including Jemini Abraham, Grace Gutierrez, Lou Montez, Patricia Singh, Sue Slattery, Jacquie Vlahos, and Relu Wiegner, as well as Mena Cali, who provided invaluable assistance in preparing the surveys for distribution.

This study has been generously funded by a grant from the Ontario Ministry of Health and Long-Term Care, including fellowship/graduate training salary support for Dr. L.K. Casaubon. The views expressed herein do not necessarily reflect those of the ministry.

\section{REFERENCES}

1. Melamed E. Reactive hyperglycaemia in patients with acute stroke. J Neurol Sci. 1976; 29(2-4):267-75.

2. Matz K, Keresztes K, Tatschl C, Nowotny M, Dachenhousenm A, Brainin M, et al. Disorders of glucose metabolism in acute stroke patients: an under recognized problem. Diabetes Care. 2006; 29(4):792-7.

3. Murros K, Fogelholm R, Kettunen S, Vuorela AL, Valve J. Blood glucose, glycosylated haemoglobin, and outcome of ischemic brain infarction. J Neurol Sci. 1992; 111(1):59-64.

4. Candelise L, Landi G, Orazio EN, Boccardi E. Prognostic significance of hyperglycemia in acute stroke. Arch Neurol. 1985; 42:661-3.

5. Christensen H, Boysen G. Blood glucose increases early after stroke onset: a study on serial measurements of blood glucose in acute stroke. Eur J Neurol. 2002; 9(3):297-301.

6. Capes SE, Hunt D, Malmberg K, Pathak P, Gerstein HC. Stress hyperglycemia and prognosis of stroke in non-diabetic and diabetic patients: a systematic overview. Stroke. 2001; 32(10): 2426-32.

7. Jorgensen HS, Reith J, Nakayama H, Kammersgaard LP, Houth JG, Raaschou $\mathrm{HO}$, et al. Potentially reversible factors during the very acute phase of stroke and their impact on the prognosis: is there a large therapeutic potential to be explored? Cerebrovasc Dis. 2001; 11(3):207-11

8. de Courten-Myers G, Myers RE, Schoolfield L. Hyperglycemia enlarges infarct size in cerebrovascular occlusion in cats. Stroke. 1988; 19(5):623-30.

9. Nedergaard M. Transient focal ischemia in hyperglycemic rats is associated with increased cerebral infarction. Brain Res. 1987; 408(1-2):79-85.

10. Chew W, Kucharczyk J, Moseley M, Derugin N, Norman D. Hyperglycemia augments ischemic brain injury: in vivo MR imaging/spectroscopic study with nicardipine in cats with occluded middle cerebral arteries. Am J Neuroradiol. 1991; 12(4):603-9.

11. Garg R, Chaudhuri A, Munschauer F, Dandona P. Hyperglycemia, insulin, and acute ischemic stroke: a mechanistic justification for a trial of insulin infusion therapy. Stroke. 2006; 37(1):267-73.

12. Song EC, Chu K, Jeong SW, Jung KH, Kim SH, Kim M, et al. Hyperglycemia exacerbates brain edema and perihematomal cell death after intracerebral hemorrhage. Stroke. 2003; 34(9): 2215-20.

13. de Courten-Myers GM, Kleinholz M, Wagner KR, Myers RE. Normoglycemia (not hypoglycemia) optimizes outcome from middle cerebral artery occlusion. J Cereb Blood Flow Metab. 1994; 14(2):227-36.
14. Capes SE, Hunt D, Malmberg K, Gerstein HC. Stress hyperglycaemia and increased risk of death after myocardial infarction in patients with and without diabetes: a systematic overview. Lancet. 2000; 355(9206):773-8.

15. Krinsley JS. Association between hyperglycemia and increased hospital mortality in a heterogeneous population of critically ill patients. Mayo Clin Proc. 2003; 78(12):1471-8.

16. Bochicchio GV, Sung J, Joshi M, Bochicchio K, Johnson SB, Meyer W, et al. Persistent hyperglycemia is predictive of outcome in critically ill trauma patients. J Trauma. 2005; 58(5): 921-4.

17. Malmberg K, Ryden L, Efendic S, Herlitz J, Nicol P, Waldenstrom A, et al. Randomized trial of insulin-glucose infusion followed by subcutaneous insulin treatment in diabetic patients with acute myocardial infarction (DIGAMI study): effects on mortality at 1 year. J Am Coll Cardiol. 1995; 26(1):57-65.

18. Van den Berghe G, Wouters P, Weekers F, Verwaest C, Bruyninckx $\mathrm{F}$, Miet $\mathrm{S}$, et al. Intensive insulin therapy in critically ill patients. N Engl J Med. 2001; 345(19):1359-67.

19. Pittas AG, Siegel RD, Lau J. Insulin therapy for critically ill hospitalized patients: a meta-analysis of randomized controlled trials. Arch Intern Med. 2004; 164(18):2005-11.

20. Fath-Ordoubadi F, Beatt KJ. Glucose-insulin-potassium therapy for treatment of acute myocardial infarction: an overview of randomized placebo-controlled trials. Circulation. 1997; 96(4): $1152-6$.

21. Gray CS, Hildreth AJ, Sandercock PA, O'Connell JE, Johnston DE, Cartlidge NE, et al. Glucose-potassium-insulin infusions in the management of post-stroke hyperglycaemia: the UK glucose insulin in stroke trial (GIST-UK). Lancet Neurol. 2007; 6(5): 397-406.

22. Canadian Stroke Network and the Heart and Stroke Foundation of Canada; Canadian Stroke Strategy. Canadian best practice recommendations for stroke care; 2006. Ottawa: 2006.

23. Adams HP,Jr, del Zoppo G, Alberts MJ, Bhatt DL, Brass L, Furlan A, et al. Guidelines for the early management of adults with ischemic stroke: a guideline from the American Heart Association/American Stroke Association stroke council, clinical cardiology council, cardiovascular radiology and intervention council, and the atherosclerotic peripheral vascular disease and quality of care outcomes in research interdisciplinary working groups. Stroke. 2007; 38(5):1655-711.

24. Broderick J, Connolly S, Feldmann E, Hanley D, Kase C, Krieger $\mathrm{D}$, et al. Guidelines for the management of spontaneous intracerebral hemorrhage in adults: 2007 update: a guideline from the American Heart Association/American Stroke Association stroke council, high blood pressure research council, and the quality of care and outcomes in research interdisciplinary working group. Stroke. 2007; 38(6):2001-23.

25. Whitcomb BW, Pradhan EK, Pittas AG, Roghmann MC, Perencevich EN. Impact of admission hyperglycemia on hospital mortality in various intensive care unit populations. Crit Care Med. 2005; 33(12):2772-7.

26. The West of Scotland Coronary Prevention Study Group. Computerised record linkage: compared with traditional patient follow-up methods in clinical trials and illustrated in a prospective epidemiological study. J Clin Epidemiol. 1995; 48(12):1441-52.

27. Canada Post. [cited 2008 Feb]. Available from: www.canadapost.ca/business/tools/pg/fsamaps/pdf/Canada.pdf.

28. Stewart A. Basic statistics and epidemiology: a practical guide. Oxford: Radcliff Medical Press; 2002.

Appendix on following pages 
Appendix - Survey

Management of Hyperglycemia in Stroke Survey

Survey

In this first section, questions pertain to your basic demographic information.

1. Your Gender:

$\square$ male $\quad \square$ female

2. Your Specialty:

\begin{tabular}{l} 
Emergency Medicine \\
Internal Medicine - subspecialty \\
$\square$ Other (please specify) _ \\
\hline
\end{tabular}

Neurology

Intensive Care

3. Years in independent practice: $\square$ 0-2 $\square$ 3-5 $\square$ 6-10 $\square>10$

4. Primary hospital practice location:
Academic (teaching) hospital
Large community hospital (with 100 or more beds)
Small community hospital (fewer than 100 beds)
Other (please specify)

5. For patients presenting to your hospital with a stroke (either an ischemic stroke or intracerebral hemorrhage), are you involved in their management in the Emergency Department $\underline{o r}$ as inpatients? $\quad$ I manage stroke patients in the Emergency Department only

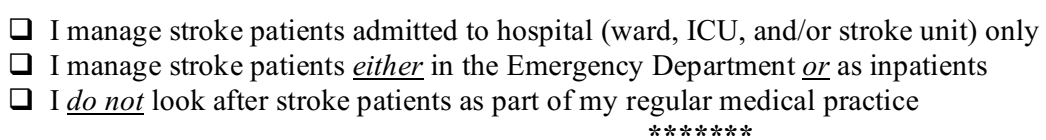

\section{If you answered "I do not look after stroke patients" to Question 5, you may stop the survey here and return it by mail in the envelope provided, or fax it to 416-603-7733. \\ If you answered "I manage stroke patients" to Question 5, please continue on to the next page.} $* * * * * * *$

In this next section, questions pertain to geneal practice information and the facility where you work. Please check off only one response per question, and please answer all questions.

6. Does your facility have a type of dedicated stroke unit described below?

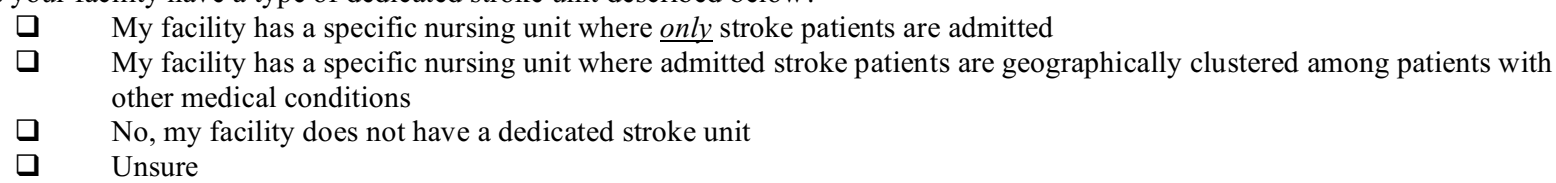

7. Does your facility have a multidisciplinary stroke team, including dedicated physicians, allied health staff (physiotherapists, occupational therapists, speech language pathologists) and nursing?
口 Yes
$\square$ No
u Unsure

8. Does your facility have medical specialists (either stroke specialists or neurologists) who routinely consult on stroke patients in your hospital?

$$
\square \text { Yes }
$$

$\square$ No

$\square$ Unsure

9. For the care of stroke patients treated at your facility, are you generally the most responsible physician or are you a consultant?

$$
\square \text { Primary physician } \square \text { Consultant } \square \text { Both situations can apply }
$$

10. Approximately how many patients with ischemic stroke and/or primary intracerebral hemorrhage (not related to tumors, aneurysms, or other vascular anomalies) do you see and care for each month?
口 1-5
ㅁ 6-10
ㅁ 11-20
$\square>20$

11. Are you aware of any specific protocols at your facility for the management of elevated blood glucose levels in stroke patients?

$$
\square \text { Yes } \square \text { No }
$$


12. Are you aware of current practice guidelines for the management of elevated blood glucose, such as the one provided by the Canadian Diabetes Association?
$\square$ Yes
№
$\square$ Unsure

13. Do you base your practice in the management of elevated blood glucose in stroke patients on a specific protocol or hyperglycemia guideline?
$\square$ Yes
№
u Unsure

The following questions pertain to your usual care practices in the management of hyperglycemia in early stroke. We recognize that there will always be specific circumstances for each patient you treat, but we would ask you to reply based on your standard practice. Even if you consult a specialist for the management of hyperglycemia (ex. Endocrinology), please complete the following sections based on how the patients under your care are usually managed. For each question, please check off one response per row (for each glucose range), and please answer all questions.

14. In a patient presenting with a stroke and with no pre-existing history of diabetes or a history of diet-controlled diabetes, how would you generally manage a blood glucose reading in each of the ranges listed below within the first 24 hours post-stroke?

\begin{tabular}{|c|c|c|c|c|c|}
\hline $\begin{array}{c}\text { Blood Glucose } \\
(\mathrm{mmol} / \mathrm{l})\end{array}$ & \multicolumn{5}{|c|}{ Management (choose only one option per glucose range) } \\
\hline $6.0-8.0$ & No treatment & $\square$ Oral agents & $\begin{array}{l}\text { Insulin } \\
\text { sub-cutaneously }\end{array}$ & $\begin{array}{l}\square \text { Insulin IV } \\
\text { infusion }\end{array}$ & $\square$ Unsure \\
\hline $8.1-10.0$ & No treatment & $\square$ Oral agents & $\begin{array}{l}\text { Insulin } \\
\text { sub-cutaneously }\end{array}$ & $\begin{array}{l}\square \text { Insulin IV } \\
\text { infusion }\end{array}$ & $\square$ Unsure \\
\hline $10.1-12.0$ & No treatment & $\square$ Oral agents & $\begin{array}{l}\text { Insulin } \\
\text { sub-cutaneously }\end{array}$ & $\begin{array}{l}\square \text { Insulin IV } \\
\text { infusion }\end{array}$ & $\square$ Unsure \\
\hline $12.1-16.0$ & No treatment & $\square$ Oral agents & $\begin{array}{l}\text { Insulin } \\
\text { sub-cutaneously }\end{array}$ & $\begin{array}{l}\square \text { Insulin IV } \\
\text { infusion }\end{array}$ & $\square$ Unsure \\
\hline$>16.0$ & No treatment & $\square$ Oral agents & $\begin{array}{l}\text { Insulin } \\
\text { sub-cutaneously }\end{array}$ & $\begin{array}{l}\square \text { Insulin IV } \\
\text { infusion }\end{array}$ & $\square$ Unsure \\
\hline
\end{tabular}

15. In a patient presenting with a stroke and with a pre-existing history of diabetes managed with oral hypoglycemic agents (OHA) prestroke, how would you generally manage a blood glucose reading in each of the ranges listed below within the first 24 hours poststroke?

\begin{tabular}{|c|l|l|l|l|l|}
\hline $\begin{array}{c}\text { Blood Glucose } \\
\text { (mmol/l) }\end{array}$ & \multicolumn{5}{|c|}{ Management (choose only one option per glucose range) } \\
\hline $6.0-8.0$ & $\begin{array}{l}\square \text { Continue } \\
\text { same meds }\end{array}$ & $\begin{array}{l}\square \text { Increase } \\
\text { OHA dose }\end{array}$ & $\begin{array}{l}\square \text { Insulin } \\
\text { sub-cutaneously }\end{array}$ & $\begin{array}{l}\square \text { Insulin IV } \\
\text { infusion }\end{array}$ & $\square$ Unsure \\
\hline $8.1-10.0$ & $\begin{array}{l}\square \text { Continue } \\
\text { same meds }\end{array}$ & $\begin{array}{l}\square \text { Increase } \\
\text { OHA dose }\end{array}$ & $\begin{array}{l}\square \text { Insulin } \\
\text { sub-cutaneously }\end{array}$ & $\begin{array}{l}\square \text { Insulin IV } \\
\text { infusion }\end{array}$ & $\square$ Unsure \\
\hline $10.1-12.0$ & $\begin{array}{l}\square \text { Continue } \\
\text { same meds }\end{array}$ & $\begin{array}{l}\text { Increase } \\
\text { OHA dose }\end{array}$ & $\begin{array}{l}\square \text { Insulin } \\
\text { sub-cutaneously }\end{array}$ & $\begin{array}{l}\square \text { Insulin IV } \\
\text { infusion }\end{array}$ & $\square$ Unsure \\
\hline $12.1-16.0$ & $\begin{array}{l}\square \text { Continue } \\
\text { same meds }\end{array}$ & $\begin{array}{l}\square \text { Increase } \\
\text { OHA dose } \\
\text { sub-cutaneously }\end{array}$ & $\begin{array}{l}\square \text { Insulin IV } \\
\text { infusion }\end{array}$ & $\square$ Unsure \\
\hline$>16.0$ & $\begin{array}{l}\square \text { Continue } \\
\text { same meds }\end{array}$ & $\begin{array}{l}\text { Increase } \\
\text { OHA dose }\end{array}$ & $\begin{array}{l}\square \text { Insulin } \\
\text { sub-cutaneously }\end{array}$ & $\begin{array}{l}\text { infusion } \\
\square \text { Unsure }\end{array}$ \\
\hline
\end{tabular}


16. In a patient presenting with a stroke and with a pre-existing history of diabetes managed with sub-cutaneous (SC) insulin pre-stroke, how would you generally manage a blood glucose reading in each of the ranges listed below within the first 24 hours post-stroke?

\begin{tabular}{|c|c|c|c|c|c|}
\hline \multirow{2}{*}{$\begin{array}{c}\begin{array}{c}\text { Blood Glucose } \\
(\mathrm{mmol} / \mathrm{l})\end{array} \\
6.0-8.0\end{array}$} & \multicolumn{5}{|c|}{ Management (choose only one option per glucose range) } \\
\hline & $\begin{array}{l}\square \text { Continue same SC } \\
\text { insulin dose }\end{array}$ & $\begin{array}{l}\text { Increase SC } \\
\text { insulin dose }\end{array}$ & $\begin{array}{l}\square \text { Insulin IV } \\
\text { infusion }\end{array}$ & $\square$ Other & $\square$ Unsure \\
\hline $8.1-10.0$ & $\begin{array}{l}\square \text { Continue same SC } \\
\text { insulin dose }\end{array}$ & $\begin{array}{l}\square \text { Increase SC } \\
\text { insulin dose }\end{array}$ & $\begin{array}{l}\square \text { Insulin IV } \\
\text { infusion }\end{array}$ & $\square$ Other & $\square$ Unsure \\
\hline $10.1-12.0$ & $\begin{array}{l}\square \text { Continue same SC } \\
\text { insulin dose }\end{array}$ & $\begin{array}{l}\square \text { Increase SC } \\
\text { insulin dose }\end{array}$ & $\begin{array}{l}\square \text { Insulin IV } \\
\text { infusion }\end{array}$ & $\square$ Other & $\square$ Unsure \\
\hline $12.1-16.0$ & $\begin{array}{l}\square \text { Continue same SC } \\
\text { insulin dose }\end{array}$ & $\begin{array}{l}\square \text { Increase SC } \\
\text { insulin dose }\end{array}$ & $\begin{array}{l}\square \text { Insulin IV } \\
\text { infusion }\end{array}$ & $\square$ Other & $\square$ Unsure \\
\hline$>16.0$ & $\begin{array}{l}\square \text { Continue same SC } \\
\text { insulin dose }\end{array}$ & $\begin{array}{l}\text { Increase SC } \\
\text { insulin dose }\end{array}$ & $\begin{array}{l}\text { Insulin IV } \\
\text { infusion }\end{array}$ & $\square$ Other & $\square$ Unsure \\
\hline
\end{tabular}

17. In a stroke patient with hyperglycemia whom you decide to treat, what target blood glucose level do you aim for?

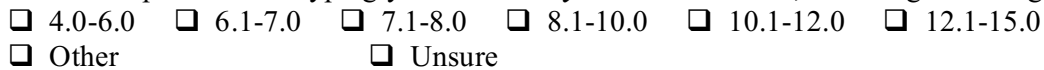

18. Within what time frame do you aim to reach the target blood glucose (from time of presentation)? $\begin{array}{cc}\square<12 \text { hours } \\ \square \text { Other } & 12-24 \text { hours } \square \text { 25-48 hours } \square \text { 49-72 hours } \square>72 \text { hours } \\ \square \text { Unsure } & \end{array}$ Other

Would you like to share any additional comments about the management of blood glucose in stroke patients?

We sincerely thank you for taking your time to complete this survey. Again, your responses will be kept confidential and data from this survey will only be released in aggregate form. 